\title{
ARTICLE \\ Balancing Trade Secrets and Right to Information in Tenders: A Judicial Study
}

\author{
Mannat Singh $\odot 1$ and Anuj Kumar Vaksha $\odot 1, *$ \\ ${ }^{1}$ Guru Gobind Singh Indraprastha University, New Delhi \\ *Corresponding author
}

\begin{abstract}
There has existed a long debate regarding the balance of right to information of every individual versus the commercial rights of businesses to protect their proprietor information. While proprietary information and trade secrets have been given protection under the RTI Act, 2005, there exists controversy regarding the protection of trade secrets due to its vague presence in the Indian legal system. Trade secrets does not have any statutory protection in India. The concept has evolved through judicial precedents which has left a huge room for interpretation and confusion regarding the laws surrounding the concept. Trade secrets on the other hand have been recognised as an exception for not revealing information under Right to Information Act, 2005. This article focuses on the matter of tenders in light of right to information and trade secrets. It articulates the courts' approach on how they view and balance adjudication of trade secret and RTI. The issue arises when. in tenders, the information provided in the bids become public documents which if made available to competitors can cause irreparable damage to businesses. The article deals with three issues namely, what information has been considered as a trade secret while exempting revelation, how the courts have treated the two parts of a tender i.e. Technical Bid and the Financial Bid and, finally it highlights certain patterns and principles that the courts have uniformly followed while deciding how to consider and allow revelation of such confidential information namely, "Fiduciary Relationship, Public interest, Pre and Post Award of Contract and Vexatious Applications".

While discussing the above issues the courts have further set up some considerations to be taken care of while dealing with each issue which has been discussed at length in this article. Therefore the research questions which the paper addresses are as follows:

i. How do courts deal with the issues related to trade secrets and confidential information while issuing information of tenders?

ii. What patterns and principles have the courts uniformly followed while deciding how to consider and allow revelation of such confidential information?
\end{abstract}

Finally the author has given suggestions on how to fill the gaps and overcome practical inefficiencies.

Keywords: Trade Secret; Right to Information; Contract; Disclosure; Tender.

\section{Introduction}

There has existed a long debate regarding the balance of right to information of every individual versus the commercial rights of businesses to protect their proprietor information. While proprietary information and trade secrets have been given protection under the RTI Act, 2005, there exists controversy regarding the protection of trade 
secret due to its vague existence in the Indian legal system. Trade secret does not have any statutory protection in India. The concept has evolved through judicial precedents which has left a huge room for interpretation and confusion regarding the law surrounding the concept. Trade secrets on the other hand have been recognised as an exception for not revealing information under Right to Information Act, 2005. This article focuses on the matters of tenders in light of right to information and trade secrets. It articulates the courts approach on how they view and balance adjudication of trade secret and RTI. The issue arises when in Tender the information provided in the bids become public documents which if made available to competitors can cause irreparable damage to businesses. The article deals with three issues namely what information has been considered as a trade secret while exempting revelation, how the courts have treated the two parts of a tender i.e. Technical Bid and the Financial Bid and finally it highlights certain patterns and principles that the courts have uniformly followed while deciding how to consider and allow revelation of such confidential information namely, "Fiduciary Relationship, Public interest, Pre and Post Award of Contract and Vexatious Applications". While discussing the above issues the courts have further set up some considerations to be taken care of while dealing with each issue which has been discussed at length in this article. Finally the author has given suggestions on how to fill the gaps and overcome practical inefficiencies.

\section{Rationale of the Study and Research Gaps}

Trade secrets are valuable information that run businesses and are quintessential for companies; therefore it becomes the duty of Public Information Officers (PIO) to protect such information. The statutory provisions have exempted issuance of trade secret information under Right to Information Act. The PIOs must understand the nature of trade secrets in order to segregate the same from common information that can be given through RTIs. This study enables us to understand how to address various issues legally that are faced by them while protecting such vital confidential information.

While reviewing the literature and case laws, it was felt that there was no legal framework available for addressing the vital issues of trade secret. This study shall highlight the issues related to fiduciary relationships, how the courts have dealt with pre and post award of contract, and vexatious applications for the public service offices, adjudicating offices and other stakeholders to understand in depth the issues related to trade secrets and right to information.

\section{Research Objectives}

i. To address issues related to trade secret under right to information act in tenders.

ii. To highlight patterns and principles that the courts have adopted while dealing with the issues of trade secret under right to information.

\section{Discussion on the Research Questions: Existing Laws and Regulations}

Trade secret is any confidential information that is of commercial value, which is not available in the public domain and the owner of the information has put in efforts to keep in a secret. It is not statutorily protected under any law in India but gains its sanctity through judicial precedents. Every entity has the right to protect its intellectual property which encourages a culture of innovation and development. On the other hand every individual also has the fundamental right to information. The essence of any democracy lies in its ability to practice transparency. In a welfare state like India where we are aiming to capitalise on our industries and uplift the society economically, socially and culturally at the same time, we face a typically peculiar situation. Accountability is the key to development in any country. When the state enters into a contract with any private entity, it is done through the process of tender to ensure fair selection. When this happens, documents in the process become public documents, making it accessible to the public. Keeping in mind this problem, RTI Act, section 8 (1) was created. However this further creates a number of issues that this article deals with.[1] states that, "If there is any information that is of public interest then the same must be open to public scrutiny."

Section 8 (1) (d) exempts disclosure of information that is an intellectual property of any entity or an individual including trade secrets, unless a larger public interest warrants disclosure. How does the court balance these interests? Under what circumstances will the court warrant or exempt disclosure? It is essential to understand the intricacies of the relationship between trade secret, RTI and public interest and how the court balances them.

Because this article specifically focuses on trade secrets, we need to understand that the same is not statutorily protected and defined. It is protected through a non-disclosure agreement in the contract and fiduciary relationship between the parties; and, therefore we cannot understand the whole concept without bringing in Section 8 (1) (e). Thus this article explains the concept of trade secrets, right to information and fiduciary relationship intertwined with each other.

Another principle that the CCI and the courts have followed is that any information sought post conclusion of a contract must be disclosed to ensure utmost transparency in the system. However, no provision is absolute and therefore has its exception which has been explained further. 
When trade secrets and confidential information or commercial value is involved, competitors will file applications and petitions for acquiring the trade secret by exploiting the system of RTI. How are these vexatious applications identified and whether locus standi plays an important role in determining vexatious petitions is something that will be explained.

When we talk about such dilemma in the law, there is bound to occur inconsistencies in the execution on the part of Public Information Officer (PIO) who will apply his discretion according to his knowledge and for the benefit of its organisation. This can result in delay, delivering incomplete information and refusal to provide information claiming exemption under RTI Act. This article talks about the consequences of these situations in the garb of section 20 of RTI Act, 2005.

\subsection{Technical and Financial Bid}

The Delhi High Court in Bharat Sanchar Nigam Ltd. vs Shri Chander Sekhar (2010) [2] held that the bidders in the technical part "may reveal to the tender calling institution their technology and processes" created by them and may not be generally in the domain moreover which the bidder may not want to disclose to other concerned parties.

The bidder through participating in the tender process Suo moto becomes entitled to all the information contained in the bids of every participant the "possibility of unscrupulous businessmen" [3] participating in the tender merely just for seeking information is a huge possibility and cannot be left unconsidered. Such revelation will disclose information that may harm competition through undercutting in the future business propositions. Access to information, under Section 3 of the Act, is the rule and exemptions, the exception. Any information can be denied only through the exemptions under section 8 or 9 of the act with a "satisfactory reason" [4] and such reason should be germane.

NALCO is an aluminium seller. It has only two competitors in the market. NALCO is a public company unlike its competitors and sells its products at the mandated prices which are displayed on its website and distributed to the shareholders. It also revises these prices. It offers a product at the declared rate but its competitors sell it at a variance. The company has a reputation of being transparent. Its competitors provide price protection sometimes and do not share their customer's information. Disclosing such information will "adversely affect the company in the long run thus the court considered it a trade secret and refused to provide the information." [5].

The court sometimes takes the stand wherein it protects the trade secrets and commercial interests of parties however many of them are so because of absenteeism of parties who are unable to prove public interest. The courts state that such protection is attributed to the failure of the respondent to be present and its lack of efforts to prove the same. The bid is given by a third party. It may incorporate financial as well as proprietary information necessary for a company which would require 3rd party information procedure u/s 11 of the RTI Act to be followed. "All these aspects need to be considered while taking a decision in this matter." [6]. But it is often seen that there is more emphasis on the principle of public interest even when there is none.

\subsection{Fiduciary Relationship}

The information regarding the connection of Nariman zone to various regions was sought for, which was allowed. Other information such as information regarding extract of take or Pay clause/Minimum Guarantee obligation clause, copy of letter informing Force Majeure clause applicability and repudiating ONGC claim, copy of agenda given to audit committee, information of provisional invoice, information regarding outstanding dues of the company, and information whether GAIL has purchased Adjusted Annual Contract Quantity of gas from ONGC or not. In this case, two legal questions were raised. One being whether there existed any confidentiality clause between two parties regarding the information being shared to any third party. And the second is whether the information sought is exempted under Section 8 (1) (d) of RTI Act. "Both these considerations were given equal weightage." [7], The existence of confidentiality clause played an important role in deciding the case. The court reiterated that many players were entering into the natural gas market as there is a huge gap in the demand and supply, leading to shortage. Thus disclosure of information would adversely affect the competitive position of GAIL in the market.

The obligation of any organisation to provide copy of question paper, its answer key and the ranks of students along with marks came up in court. The four key issues that were up for consideration in the court were of public interest, ambit of the above as trade secrets, fiduciary relationship between the faculty and AIIMS, and whether AIIMS is a profit oriented organisation and if such organisation can even claim exemption of adverse competition under RTI Act.

AIIMS contended that the question paper and their answer key is created by faculty members and experts therefore it is their intellectual property right. This gives rise to the fiduciary relationship between the organisation and the experts and enabling others to replicate their work. This contention was rejected by the court. In order to ascertain this, a few elements need to be fulfilled. There needs to be a person who occupies a position of trust to act for the benefit of that person, i.e., who has some duties, holder of information must have a choice, information given must be for the benefit of the receiver. "Thus, an information given during a job, licence, statutory requirement cannot be considered to be of a fiduciary relationship." [8]. These experts are in a competitive business and their disclosure could harm their edge over others. Thus in this case there exists no such relationship. The same 
was in the case of ICAI where court allowed the disclosure of question papers along with its key, model answer solutions as well as the instructions given during and after the examination to the examiners and the moderators. It was also held that "once the evaluation of answer sheets is complete there is no harm to any third party." [9], In government institutions many documents may be considered as confidential however, they need to be provided with the advent of RTI Act. The courts have treated 'public interest as an exemption to the exemptions in section 8. This judgement was widely criticised by the fraternity. Adjudicating every legal issue "in the name of public interest is beyond the adjudicating authority" [10] and will go against the spirit of the act. This is how most of the RTI petitions are adjudicated in CIC while considering the exemptions under section 8 . The issue was challenged in High Court where it reversed this judgement and considered the above as the intellectual property rights of AIIMS, thus exempted from disclosure. However, this rule would be applicable only to this case as they claimed "limited question bank" as a defence. In 2012, a case came up highlighting two issues, whether any person other than the examinee can ask for disclosure of question papers considering the possibility of coaching centres and other such entities trying to cash on such information. The court did not allow any person other than the examinee himself to claim such information.

The court stated that the information is not for the benefit of the organisation thus rejecting one of the above contentions, however it fails to take into account the competitiveness between institutions to obtain the best students through maintaining its quality standards and forcing such institutions to provide the above information is depriving them of their unique approaches. Finally whether AIIMA is a commercial organisation, the court rejected the claim and said that it does not compete with other organisations and thus section 8 (1) (d) cannot be invoked. "Section 22 the Act overrides other laws, the opening non-obstante clause in Section 8 confers primacy to the exemptions enacted under Section 8(1)" [11]"Thus, once the information is found to be exempt under Section 8(1), reliance on Section 22 is misconceived. Whether the information is of such nature as defined in Section 8(1)(d) of the Act, can be adjudicated only by recourse to Section 11 of the Act." [11]

Particulars of loans, advances beyond Rs. 1 crore written off , orders of competent authorities authorising such write offs, closures and one $\neg$ time settlements to both private and public sector borrowers along with name and addresses of customers. Can such information be disclosed to any party?

Can a bank be asked to disclose information regarding particulars of loans, written off loans, authorisation for the loans, name and addresses of customers? It can be said that the disclosure of such information is for the larger public interest since a large amount of money has been lost. This money belongs to the public therefore, these documents should be public documents and every stakeholder should have the right to such information. The opposition says that such information is a company's trade secret. Moreover, they have a fiduciary relationship with their customers. More so they are protected by their right to privacy. The reason why we think that this data would not be covered by the exemption provisions is because it relates to only those loan accounts in which the authorities had written off the bad debts. To the next contention, it was held that the fiduciary relationship between the bank and the customer ended the moment the customer stopped the repayment.

The bidders need to disclose information about themselves, the company, its turnover, processes and other things that may enable the competitors to evaluate the bid of the company. Even if we say that once the bid is complete, all information can be provided, it will still hamper the competitive position of the said company for any future tenders. The technical bids contain intellectual property information and trade secrets such as which technology the bidder may use for which "type of clients, the manner of execution, customary business practices" [12] which is of utmost importance to them. Such disclosure will adversely affect them in future awarding of contracts and tenders.

\subsection{Public Interest}

During events, third parties try to extract information having commercial value such as sources of sponsorship, amount of commission paid and expenses on legal issues and consultancy. Here the court was of the view that such information is the "essence of any event management and planning." [13]. It provides the businesses with competitive edge that enables it to capture the market. Thus, it considers such information to be a trade secret and considers it as an exemption under section It also states that such information will not serve any public information whatsoever.

A tender completion requires two considerations to be accepted. It contains a technical bid and a commercial bid. Usually when the petitioner seeks information about the two, the court needs to provide information in the light of section 8 of RTI Act. For this court applies the doctrine of severability under 10(1) of the RTI Act. The court severed "those parts of documents that do not reflect any intellectual property or a trade secret and disclose them." [14]. The appellate authority after considering any question of law directs the case back to CIC or PIO where they are asked to segregate the parts of a document or minutes of a meeting and further dispose of the complaint.

Many times, after the tender is completed and the contract is signed with the said company, changes are required to be done with regards to the technical aspect of a technology. When this happens there is bound to arise some kind of scrutiny where the competitors will want to know in details the shortcomings in the technology, what changes were suggested in order to ensure whether the company in question did meet the initial technical requirements or 
not. However, all such details are proprietary information or trade secrets. In order to reveal this information to the public, we need to understand and balance the need, intention, objective and effect of the same. The courts have again and again reiterated that "no such information can be revealed unless there is some public interest that needs attention" [15]. Thus, we need to understand what and how courts perceive and dispose of such cases. The copies of intimation of changes would involve some discussion on technical specification itself, hence the same is exempted $\mathrm{u} / \mathrm{s} \mathbf{8}(1)(\mathrm{d})$ of the RTI Act. The PIO responded that such information cannot be disclosed as it is not related to any public activity.

Information relating to, "tender documents can by no stretch of imagination be considered personal information" [16] which could constitute invasion on the privacy of any individual. What the issue at hand is the "balance that needs to be struck between public's access to public documents for promoting transparency, protection of private rights of an individual to his intellectual property right and principle of confidentiality." [16], Based on this decision, the future course of action shall be planned with regards to the government's and people's ability to obtain information in the future.

The commercial bid of a tender usually states the amount that one is willing to spend and the expected work and the annual estimated turnover of the project. After doing so it invites applications who are willing to fulfil the criteria. It also asks them to provide basic information about the company, year of establishment, name of directors, managers, promoters, proof of experience, copy of trade licence, list of detailed equipment, strength of employees. After they have sought for the company's credentials, they ask for the estimated cost of project, time to be taken for the completion of the project, earnest money, cost of tender, company turnover, IT returns and other relevant documents.

Many of these documents are already available in the public domain. However, some of them are the proprietary information of the company. The issue with trade secrets protection is that there is so much confusion related to what exactly constitutes trade secret, how do we aim to protect the same. Even though it is broadly defined as any information that the holder of information puts efforts in keeping it a secret, and which is not available to public at large, and which gives a commercial edge to the person could be treated as a trade secret. However, according to this definition, a lot of information provided in the technical and the financial bid can be considered as a trade secret, but due to the lack of a definite cohesive definition, this does not happen. The information documents submitted by M/s Beigh Construction Private Limited involve commercial confidence trade secrets and intellectual property of his company - RTI Reply The courts have been seen to be taking a definite stance when it comes to any intellectual property such as a copyright, patent or a trademark, however, they have been hesitant in taking a bold step when it comes to protection of trade secret. Trade secrets are not seen as proprietary information that needs definite protection by courts. "They have perpetually outweighed public interest with trade secrets." [17] Successful bidder shows the malafide intention of the respondent as the same is tantamount to ensuring that no person can verify the actual qualifications of the successful bidder from the angle of probity and people cannot misuse the provision in the garb of transparency.

In the case of providing "facility of smart card based registration certificate" [18], the question came up whether providing agreements and contracts would fall under the ambit of trade secret and whether the same will hamper the competitive position of the party. The respondent took a plea to look at this case not from the ordinary perspective but also considering the security perspective. The State information Commission held that the information sought will contain trade secrets and intellectual property. However the High Court of Bombay reversed this view and held that there was nothing in the information sought by the Respondent, by which any commercial information is being disclosed.

"Section 98 of the Delhi Value Added Tax Act, (2004) makes such returns confidential and specifically stipulates that all particulars contained in any statement made, return furnished or accounts or documents produced in accordance with this Act, or in any record of evidence given in the course of any proceedings under this Act, other than proceedings before a criminal Court shall be treated as confidential and notwithstanding anything contained in the Indian Evidence Act, 1872, no court shall, save as aforesaid, be entitled to require any servant of the Government to produce before it any such statement, return, account, document or record or any part thereof, or to give evidence before it in respect thereof. Thus this provision protects and insulates the persons filing such returns and even the Court is not entitled to summon the records except when the proceedings are before a Criminal Court or what is saved under Sub-Section (3) of Section 98 of the Act. Not only this, Sub-Section (2) Section 98 of the Act provides for punishment with imprisonment upon the government servant who discloses such information."

Month wise Vat on transactions, annual bank statements and parties name, details of debtors and creditors, date of opening and closing of stock, copy of DVAT, trading and profit and loss accounts, balance sheets, details of all partners, details of tax scrutiny cases, details of assessment order of tax cases were sought. CIC also was of the opinion that the information could not have been divulged to the appellant inasmuch as no public interest was involved or could be shown / established by the appellant. The CIC, in the process, made scathing observations stating that this case depicts how a weapon designed to ease problems of the citizen is at times being misused and totally abused in the hands of people like the appellant to settle personal scores. It was further observed that the public authority providing information to such warring siblings is also in its own way permeating creation of bad blood and recommended that some way should be found to resolve and avoid such revengeful and negative atmosphere and unhealthy competition. 
It is trite law that insofar as evaluation of tenders and award of work in connection with public works is involved, the competent authority must do its exercise in a reasonable and non-arbitrary manner. Such a procedure has to be transparent. This is also based on the principle that the public largesse are not to be distributed by the Government functionaries at their whims and fancies and all have equal right to be considered and all eligible persons have to be considered for award of public works. Thus the method of evaluation of tender has to be transparent. In a particular case, if it is found that the exercise done was not in accordance with the tender conditions or was arbitrary, the same can be set aside / quashed. "It is in this light, that the right to know the basis of tender documents, the eligibility of a tenderer or the manner in which bid is decided comes within the domain of larger public interest." [19].

When the court has to weigh in public interest and the proprietary interest in terms of equity and balance of convenience, then the role of judicial review comes up. What exactly would comprise of a trade secret, whether such trade secret can be legitimately protected, in what circumstances can we reveal such proprietary information? While deciding on matters of contracts entered on behalf of state the Court is generally stressing on whether there has been any infirmity in the "decision making process"[20]

Public interests are above all and every participant must be treated equally. "The government is free to enter into a contract with any person or an organisation but cannot do so arbitrarily without a legitimate cause." [21] "It can reject even the lowest bidder if is done in the interest of public." [22]. If so, then can an individual seek proprietary information taking the plea that the government rejected the lowest bidder. Does this show the wrongful intent of the petitioner, or is it a matter of right of every individual to claim any information on this basis.

Can the respondent take a plea that the disclosure of proprietary information should be barred in an arbitral proceeding? The court held that it being in the nature of any other Court proceedings, demands utmost transparency; thus such a plea shall not sustain. Moreover, "arbitral proceedings are not in the nature of investigation so as to debar accessibility of documents relied upon, since" [23], Arbitration does not debar the disclosure of any public document in a similar way like any other Court proceedings. Will section 8 (1) (d) seize to be applicable if the appellant seeking the information is the partner of the firm in question who received the tender. The court held that Section 8(1) (d) of the RTI Act 2005 does not apply in this case since the person seeking information is the appellant himself who is also the partner of the company whose information has been asked for.

When the time of non-disclosure has elapsed and the tender has been scrapped, even then the revelation of any such information would be included in the evaluation process and should be sought through the procedure under Section11 of the Act. There may still be crucial information to be protected thereafter. Information relating to technology can be said to be covered in this category. Similarly, "the minute details of the bids submitted by various parties may also said to be broadly covered under this clause."[24] The plaintiff wanted the Report of Evaluation of Tender on the Financial Bids received from various bidders in respect of all the Zones. The court held the "Evaluation Report does not contain any technological information"[24], even though it does contain elements of financial information about the bids. It, thus, appears to us that the Evaluation Report per se does not contain any information which is barred from disclosure under clause (d). The court ordered for disclosure of limited information in the evaluation report as it would not affect the parties at this early stage. The confidentiality clause has no more value once the time has elapsed. Moreover it will be in the larger public interest to disclose parts having irregularities in report on Tender Evaluation in the Financial Bids.

The petitioner asked for information regarding details of the lessee wise and lease wise scheme of mining submitted for approval with name of the Recognized Qualified Person (RQP), area, mineralogy, in situ and replenishable reserve, yearly mineable area and quantity shown in the draft scheme mines.

The disclosure of the requested information is in public interest because such disclosure would help in ensuring that the "mining leases are granted as per the government instructions and the approved mining plans and the disclosure would also control the illegal mining activities."[25]

It being so, the information is exempted from disclosure under Sections 8(1)(d) of the RTI Act. "However, limited financial information as to the financial quotation/price quoted by the third party in the said tender be provided to the appellant, as the disclosure of the same, at this belated stage is not going to cause any harm to any of the parties." [3].

MMTC is a corporation indulged in the business of Gold, Silver and Precious Metals on National and International levels. Commission is of the view that the disclosure of the desired information which includes inventory of various items, inventory of packing material, fabricator-wise accounts/party ledger, supplier-wise accounts/party ledger, wastage on the total quantity of gold year-wise, copy of tenders in the last 3 years. purchase orders, basis of fixing making charges and item wise rates are information of the nature of disclosing price sensitive information in relation to the business of the respondent deals which in this case is gold and silver, would attract provisions of Section 8 (1) (d) of the RTI ACT, 2005. However, in the "interest of transparency, the Commission has directed the CPIO to provide the list of Jewellery items procured and sold along with the list of suppliers/fabricators without disclosing the cost to the appellant within four weeks from the receipt of the order." [26]

There still are the exemptions under section 8. "Once we hold that the information of which disclosure is sought relates to or contains information supplied by a third party and which the third party may claim confidential, the third-party information procedure laid down in Section 11 of the Act is attracted." [27]. "The information of commercial confidence must be severed and rest of the relevant information must be provided." [28] 
Appellant filed an RTI to seek information regarding a tender by the BSF. He sought for copy of A/A, technical sanction, award letter, completion certificate, completion cost of the infrastructure and the mode of executing the project. BSF is an organisation which has been listed in the second schedule, therefore according to Section 24 of RTI Act, any such information sought regarding an organisation listed in second schedule cannot be allowed except in cases of corruption and human rights violation. "Even though the court had accepted that the petition implies allegations of corruption, however, the same cannot be construed directly." [29]. Therefore the appeal was dismissed. The respondent had taken the plea of exemption under section 8 (1) (d) and under section 24 . The connection between these raises a very important debate. There is a need to balance, the right of an individual as a common man and a stakeholder in the society, the right of the companies who took part in the tender process to seek information in suspicion of corruption, the protection of such organisations under section 24 and the protection of such organisation under section 8 (1) (d). If the proviso of Section 24 (1) is not enough to accept an application per se then what is? Is the information sought in itself not an allegation of corruption? Does an appellant need to allege corruption charges in the RTI itself? The information sought and the arguments of the appellant directly reflect allegations of corruption, but the court failed to accept them, impairing the basic right of the party to raise their voices in cases of corruption.

When commercial information is sought from a "public organisation regarding sensitive issues concerning security there is always a dilemma regarding the extent of information that can be provided to the applicant." [30] Will public interest principle play a role when the organisation is claiming exemption under Section 8 (1) (a) and Section (1) (b) or is the exemption absolute. When RTIs are filed in security organisations there will always be threat to the security, sovereignty and integrity of a nation. The courts have given weightage to public interest in such cases Even though it has not granted information liberally in these cases, however, it is stated that importance must be given to issues of public imtrest.

To what extent can the plea of a highly competitive market be taken by the respondent, when the court is considering the balance between public interest and individual's proprietary rights. It was further submitted that they have entered into a contract with the third party and that divulging any information relating to it would tantamount to breach of their fundamental rights.

This kind of information would directly disclose the pricing policy of the assessee which would "jeopardise the bargaining power available to the assessee since the data as to costs would be available to all agencies dealing with the assessee."[31]. The information of businesses must remain confidential unless necessary for larger public interest.

A disclosure of monthly average of RTD for the transportation or any such document that may reveal the pricing policy of an organisation will come under the exemption of trade secret as it jeopardises the bargaining power of the company as the data regarding cost will be available to all those dealing with the assesse. If the nature of information is such that disclosure of which may have the propensity of harming one's competitive interests, "it would not be necessary to specifically show as to how disclosure of such information would, in fact, harm the competitive interest of a third party."[32]. The framework of the RTI Act, 2005 restricts the jurisdiction of the Commission to provide a ruling on the issues pertaining to access/ right to information and to venture into the merits of a case or redressal of a grievance.

\subsection{Post Award of contact}

Even after the award of contract, "the information available with the public authority does not cease to be personal information in relation to the party who submitted this information."[27] Therefore, this information cannot be disclosed without following the procedure prescribed $\mathrm{u} / \mathrm{s}$ 11(1) of the RTI Act.

Another issue that comes up is when the selection criteria is changed post selection and finalization of the contract. In a case where selection criteria was changed from cost based selection to quality based selection, the appellate sought for the note sheet that regarding change of the criteria and its approval from the competent authority. Here providing the note sheet would have meant supplying all the discussion which would entail the trade secrets and intellectual property of the organisations.

The court here emphasises on the fact that no information is to be kept confidential once the tender is decided and the work order is issued. It focuses on the need for more transparency in the system and the spirit of RTI. The court has consistently overlooked the rights of proprietors, businessmen and individuals whose rights have not been given much weightage. While weighing in the balance between public interest and intellectual property rights, it becomes our duty to judicially segregate and classify the rights of both the parties while upholding the essence justice through considering doctrine of balance of convenience and rule of law.

The principle that has been upheld consistently is that any document cannot be kept confidential once the tender process is completed and the contract has been awarded. The court stated, ", the document in question cannot be treated as trade secret or commercial confidence". Once the tender process has been completed and the disclosure of documents cannot influence the contract. This statement may be true in part when it comes to the documents of a financial bid. However the same is absolutely untrue when it comes to any trade secret and intellectual property. The disclosure of information in respect of the document of the bidder shall hamper the healthy competition of the prospective tenderers and this aspect of the matter has not been considered either by the Authority under Right to 
Information Act or by the learned Single Judge.

When a person who is unrelated to the matter seeks information through RTI, the question arises whether that person has a locus standi to make such a request. The courts have often reiterated that every person, being a citizen of the country and a stakeholder of the society whether a party to the issue or not has an equal right to seek information to maintain transparency. Every person has the right to know every public act by public functionaries. Every agent of the government needs to be held accountable.

The court has emphasized on the importance of the right to know. It holds it as the ultimate right against oppression, bureaucratic interest, personal benefit and corruption. "To concede to a sacrosanct secrecy in a Court of justice is to attribute to them a character which for other purposes is never maintained-a character which appears to have been advanced only when it happens to have served some undisclosed interest to obstruct investigation into facts which might reveal a liability." [33]

The courts say that the ordinary practice must be disclosure at all times in business transactions and if at any time a genuine case arises of inviolate secrecy, then the same can be decided on merit. However it has been reiterated in courts that when a dilemma arises about right to information verses protection of trade secret and intellectual property, then such must be protected at all times and such disclosure cannot be allowed until and unless there is an absolute necessity to reveal such information for the public interest. Such disclosure should be done as a last resort. This shows us the juxtaposition in approaches that the courts have taken. There is a stark variation in the approach that the courts have adopted in this respect.

People have a right to know the basis on which the decision has been taken. "If tenders are invited by the public authority and on the basis of tender document, the eligibility of a tender or a bidder is decided, then those tender documents cannot be kept secret, that too, after the tender is decided and work order is issued on the ground that it will amount to disclosure of trade secret or commercial confidence." [25] If the authorities of government refuse to disclose the documents, the very purpose of the Act will be frustrated."

The contention remains the same. "That once the bid has been completed and the contract has been signed, the respondent cannot refuse to provide the documents unless it consists of the intellectual property of the individual [16]."

A contention that a "technology development contract" is a proprietary document and thus they were not in a position to provide definitive design submitted by the third parties post finalization of this tender also. The PIO, RDSO submitted that some change(s) of design including change of technical parameters were involved as the subject was new and the knowledge available with the public authority was limited.

It is stated that the cost implication for the post tender design modifications is also not the intellectual property of the third party, therefore the parties are bound to provide such information. There is also an "inconsistency in the treatment of information" sought by a party regarding the changes made post the finalisation of tender. In this case, the court held that because the discussion regarding the changes will contain references to trade secrets and intellectual property. The same is therefore exempted under sec 8 (1) (d) of RTI Act.

The essence of any tender or a bid is confidentiality. It enables the parties to maintain their competitive edge over the others. Once it would affect the parties adversely. When we talk about the financial bid, every bid needs to be kept a secret which will guard him against corruption. Which is why the courts have upheld the secrecy of such information until the contact is concluded. However the issue with this principle is that the bids are not only confined to the price, it contains host of information about the company. The possibility of unscrupulous businessmen participating in the tender merely for acquiring such information cannot be ruled out. Such disclosure may lead to the competitors undercutting in future bids.

Reference to US law has been made repeatedly which says that unless persons having necessary information are "assured that it will remain confidential, they may decline to cooperate with officials and the ability of government to make intelligent well-informed decisions will be impaired."[21] Another test is to see if the information is generally available in the public domain or not and if the businesses have made such information available to the public at large.

\subsection{Vexatious RTI}

At times when applicants in a tender are rejected, the competitors file vexatious RTIs to hinder the process of tender and to retrieve important commercial information which may be of use to them in future processes. In such cases, can the applicant be prohibited from requesting repetitive interrogation and making baseless allegations. Filing an RTI is a fundamental right of every citizen of the country, making it extremely difficult for the system to stop a person from exercising his right. Further are the PIOs obliged to reply for the information that is already available in the public domain or which is the information, otherwise retrievable by the querist by resort to Section 610 of the Companies Act.

The exemption under Section 8 of RTI Act provides organisations a shield for their protection where they can legitimately choose to not disclose certain information. However, what they consider as legitimate may seem deliberate non-compliance and malafide disregard for the process to the information seeker. The public authorities may claim that they bonafidely believed such stance to be genuine. Can the authorities thus be penalised under section 20 of the RTI Act. The courts have held that only because the appellant body have found that PIO was 
incorrect in not responding or not disclosing information, it cannot automatically lead to imposition of penalty and issuance of showcase notice. This provision has been made only when there is malafide or unreasonable conduct. Specifically in cases where the PIO refuses any information arbitrarily without reasonable cause or provides misleading, incorrect or incomplete information. Imposing penalties on wrong judgement would mean disturbing their day-to-day functioning. It would be harmful for the long term development of the Act and would lead to skewed and imbalanced decisions by PIO's and the appellant bodies.

However, a "two-year delay without reasonable cause was condoned and considered to be lackadaisical approach." [34] But the court could not identify any malafide intent, which is why and it further refused to initiate an action under Section 20 of RTI Act. Section 20, no doubt empowers the CIC to take penal action and direct payment of such compensation or penalty as is warranted. Yet the Commission has to be satisfied that the delay occurred was "without reasonable cause or the request was denied malafidely" [35]

The Act encourages an openness culture in the public sector whose actions have an impact on people's lives. It is the duty of public organisations to provide the information sought unless exempts the disclosure. It is meant to create an environment of transparency for a robust democracy. "The reason for prescribing time limit is to ensure execution."[36]. However, this does not bind organisations to become victims of vexatious acts by people which is why section 20 cannot be interpreted rigidly.

"The PIO is expected to apply his / her mind, duly analyse the material before him / her and then either disclose the information sought or give grounds for non- disclosure." [37]. Thus the PIO cannot refuse to reply on grounds that such information could not have been disclosed. It is the "duty of the PIO to ensure that adequate information is provided under the statutory requirement[37]." Section 5(4) strengthens the PIO's authority. If he finds any issue with the people seeking information then he can recommend some remedial action which makes him an essential part of the system of RTI. "PIO is the custodian of information and it is him who must be held accountable and penalised in case of default not the appellant authority[38]. "

\subsection{CIC Powers}

It is the sole discretion of the CIC to take a decision regarding penalising. The legality of the fact that whether the CIC had the discretion to restrict penalty as provided under Section 20 of the Act is mandatory, is no longer res integra.

Information seeker cannot "as a matter of right claim audience in the penalty proceedings which are between the CIC and the erring information officer[38]." "And neither there is any provision in the Act for payment of penalty or any part thereof imposed/recovered from the erring information officer to the information seeker." [30]

When RTIs are filed and the day to day receipts of tenders and appointments are sought, it becomes difficult for the courts as well as the public authorities to cater to each and every petition. "While the right to information is a fundamental right, the burden such applications have on the daily functioning if the organisations is quite significant."[39].

The courts have found it difficult to balance the two. This dilemma has come up in many cases where the court admits that allowing such petitions would hamper the effective functioning of public authorities by increasing the paper work significantly. The courts find themselves helpless as they are unable to reject such applications but have reiterated often their dilemma in the court.

CIC can only decide whether a particular set of information should be disclosed or not, it should "not dwell into their legal rights." [40]. This function is not considered as a judicial one but an administrative one. "CIC has been delineated under this act and must act within the confines of the act. It is neither required to nor has the jurisdiction to examine any other controversy or disputes.

CIC needs to ensure that the information sought for has been provided, if denied then whether the basis for denial is justified, it has the "power to penalise the PIO and finally whether any direction under Section 19(8) were warranted." [32]. It also executes functions under Section 25 and 18.

\section{Conclusion}

There are no statutory provisions related to trade secret laws in India. They have been developed and evolved through cases in courts forming important legal principles and concepts for regulation of stakeholders and interested parties. The first issue that this research paper formulates is regarding the balance that is to be set between transparency in the public domain through right to information and the protection of one's trade secret as a proprietary commercial right of an individual and the issues arising thereof. It talks about the issues that the government institutions face while issuing tenders which are public documents and contain certain level of proprietary information of companies. The court has taken a stand wherein it protects the trade secrets and commercial interests of parties however many of them are so because of absenteeism of parties who are unable to prove public interest. Another principle that the CCI and the courts have followed is that any information sought post conclusion of a contract must be disclosed to ensure utmost transparency in the system. However no provision is absolute and has its exception which has been explained further. While considering the principle of fiduciary relationship the court raised four key issues that were up for consideration in the court which were of public interest, ambit of the 
above as trade secrets, fiduciary relationship between the faculty and AIIMS, and whether AIIMS is a profit oriented organisation and if such organisation can even claim exemption of adverse competition under RTI Act. The court stated that the information is not for the benefit of the organisation thus rejecting one of the above contentions. Finally, whether AIIMA is a commercial organisation, the court rejected the claim and said that it does not compete with other organisations and thus section 8 (1) (d) cannot be invoked

Can a bank be asked to disclose information regarding particulars of loans, written off loans, authorisation for the loans, name and addresses of customers? It can be said that the disclosure of such information is for the larger public interest since a large amount of money has been lost. This money belongs to the public therefore these documents should be public documents and every stakeholder should have the right to such information. To the next contention, it was held that the fiduciary relationship between the bank and the customer ended the moment the customer stopped the repayment.

During events, third parties try to extract information having commercial value such as sources of sponsorship, amount of commission paid and expenses on legal issues and consultancy. Here the court was of the view that such information is the "essence of any event management and planning." [13]. It provides the businesses with competitive edge that enables it to capture the market.

Tender details are proprietary information or trade secrets. In order to reveal this information to the public, we need to understand and balance the need, intention, objective and effect of the same. The court has again and again reiterated that "no such information can be revealed unless there is some public interest that needs attention".

The court here emphasises on the fact that no information is to be kept confidential once the tender is decided and the work order is issued. It focuses on the need for more transparency in the system and the spirit of RTI. But in some cases, even after the award of contract, "the information available with the public authority does not cease to be personal information in relation to the party who submitted this information."[27] Therefore, this information cannot be disclosed without following the procedure prescribed u/s 11(1) of the RTI Act.

Finally, regarding vexatious RTIs. the applicant be prohibited from requesting repetitive interrogation and making baseless allegations. Filing an RTI is a fundamental right of every citizen of the country, making it extremely difficult for the system to stop a person from exercising his right.

\section{Implications}

As trade secret laws are not statutorily codified and fall under numerous domains of law, this research will serve as a guide for practitioners, academicians and especially administrators of universities for executing projects and administrative work. It lays down legal framework of tendering and university procedures with respect to trade secret laws which are protected under RTI Act. This research paper dwells into nuances of trade secret viz a viz RTI which will enable administrators to understand how to balance these two concepts while executing developmental projects and also to resolve conflicts when any arise between companies or between companies and administration. Finally it will help the administrators to understand the relationship between companies, universities and other governmental institutions who face the conflict between proprietary rights and public rights while developing or sharing trade secrets in their businesses while tendering.

\section{Recommendations}

i. Codification of trade secret laws is a must without which the certainty of its legal regime will remain vague and legal decisions will be left upon the doctrine of "balance of convenience", thereby weakening the rights of trade secret laws.

ii. More protection should be awarded to fiduciary relationships while deciding cases which are not the case in reality. We have observed that courts tend to become lenient by not restraining trade under section 27 of Indian contract act, which in turn weakens the trade secret law.

iii. The period of 2 years in post award of contact should be applicable only to general trade secrets weighing in their importance however the limitation period of information which is of extreme importance should be extended.

iv. The RTI procedures are weak and the officers must be well equipped and educated to understand the gravity of information that may be provided as trade secret laws to the public which may also be due to vexatious complaints. Therefore there must be training sessions for RTI officers for the same.

\section{References}

1. Singh, S (2019) Non-disclosure of intellectual property as information under the right to information act, 2005, central information commission.

2. Bharat Sanchar Nigam Ltd. vs Shri Chander Sekhar, (LPA No LPA No. 900/2010).

3. Mr. Ajay Chadha vs Ndmc, Gnct Delhi, CIC/DS/A/2013/001664-YA.

4. Mr. Harpreet Singh vs Ministry of Communications, No. CIC/BS/A/2013/ooo681/4968. 
5. Mr. Akhand vs National Aluminium Company Ltd, F. No. CIC/YA/A/2014/900212.

6. Mr. Shubho Chakravarty vs Ministry of Power, File No. CIC/LS/A/2011/o03979.

7. P Suresh vs Gail (India) Limited, 2017.

8. Ms. Sakshi Mathur vs Ministry of Health and Family, CIC/SG/A/2011/o03226/17096.

9. Institute of Chartered Accountants of India v. Shaunak H. Satya and Ors, CIVIL APPEAL NO. 7571 OF 2011.

10. Entrance exam paper, answer key should be disclosed. CIC, The Economic times, 2010.

11. Vijay Prakash v. Union of India AIR 2010 Delhi, W.P. (C) 803/2009.

12. Mr. Kodur Venkatesh vs Andhra Bank, File No. CIC/SH/A/2014/oo1222.

13. Kirti Azad vs Ministry Of Youth Affairs and Sports, Second Appeal No.: CIC/KY/A/2016/oo1025.

14. Ms. Sarika Jain vs National Hydroelectric Power, Case No. CIC/SS/A/2013/o02489.

15. Himanshu Pathak vs Ministry Of Railways, File No.: CIC/VS/A/2015/ooo661.

16. Shri. Md Anwar vs Department Of Atomic Energy, Appeal No CIC/SM/A/2011/ooo524/SG, 2011.

17. Sudhanshu Aggarwal vs Ircon International Limited, File No.: CIC/IRCON/A/2017/127023.

18. M/S Shonkh Technology ... vs State Information Commission, WRIT PETITION NO.2912 OF 2011.

19. Ashok Kumar Goel vs Public Information Officer Vat, LPA 190/2012.

20. Sterling Computers Limited Etc vs M and N Publications Limited, 1996 AIR 51, 1993 SCR (1) 81.

21. $M$ /s. Monarch Infrastructure (P) Ltd. vs. Commissioner, Ulhasnagar Municipal Corporation and others Appeal (civil) 3288 of 2000 .

22. Orissajob.Com vs State Of Orissa and Others W.P.(C) No.28101 of 2011.

23. Mr. Anil Agrawal vs BSNL, Ambala CIC/AD/A/o9/ooo51/AD.

24. Mr. Chander Shekhar vs Ministry of Communications File No. CIC/AD/A/2009/oo1366.

25. Drd Dhaya Devadas vs Ministry of Mines, (2012.

26. Mr. Abhishek vs Ministry of Heavy Industry, Case No. CIC/SS/A/2012/001285.

27. BSNL V Shri V. Chandrasekhar.

28. Mr. Tirath Pal Ravi vs Ministry of Defence.

29. Er. A. K. Bhatnagar vs Border Security Force (BSF), Appeal No.CIC/WB/A/20o8/o0169.

30. Varun Krishna vs SPMCIL Security Printing Press.

31. Naresh Trehan vs Rakesh Kumar Gupta W.P.(C) 85/2010 and CM Nos.156/2010 and 5560/2011, W.P.(C) 251/2010 and CM No.526/2010.

32. General Secretary vs Bharat Petroleum Corporation, Second Appeal No.:- CIC/BPCLD/A/2018/103306-BJ.

33. State Of U.P vs Raj Narain and Ors on 24 January, 1975 AIR 865, 1975 SCR (3) 33.

34. Bhagat Singh v. CIC and Ors146, (2008) DLT 385.

35. Rajendra Singh v. Central Information Commission and Anr,. WP (C) 5469 of 2008.

36. Mujibur Rehman vs Central Information Commission (W.P. (C) 3845/2007).

37. J P Aggarwal v. Union of India (WP (C) no. 7232/20o9.

38. R.K. Jain vs Union of India, LPA No. 369/2018.

39. Mr. Harbhajan Singh Toor vs Ministry of Shipping, Road.

40. Union of India v. Namit Sharma, REVIEW PETITION [C] No.2309 OF 2012. 